Araștırma Makalesi - Gönderim Tarihi: 16 Eylül 2019 - Kabul Tarihi: 26 Kasım 2019

\title{
Türkçede Beden Olgusu: Atasözleri ve Deyimler Üzerine Bir İçerik Analizi
}

\section{Emet GÜREL ${ }^{1}$ \\ Merba TAT ${ }^{2}$}

Öz

İnsanın fizyolojik varlığının taşıyıcısı olan beden, toplumsal yönüyle de kültürel değer ve inançların taşıyıcısıdır. Çağcıl dünyada birçok disiplinin ilgi alanına giren beden, dilbilim ve kültür araştırmalarının önem atfettiği çalışma konularından biridir. Bir toplumun kültürünü oluşturan temel unsurlardan olan dil, o toplumun deneyimlerinin biriktirilmesini ve kuşaktan kuşağa aktarılmasını olanaklı kılmaktadır. Ifade gücünü zenginleştiren dilsel araçlar olan atasözleri ve deyimler; bir kültürün yaşam biçimi, yönelimleri, inançları, gelenekleri ve değerleri hakkında bilgi veren söz yapılarıdır. Atasözü ve deyim araştırmaları aracılığıyla bir kültürün belirli olay, olgu ve durumlara yüklediği önem ve değeri analiz etmek mümkündür. Bu çalışma, Türkçede beden olgusunun yerini atasözleri ve deyimler üzerinden mercek alıına almayı amaçlamaktadır. Çalışma kapsamında Türk Dil Kurumu Atasözleri ve Deyimler Sözlüğü araştırma evreni olarak seçilmiş, gerçekleştirilen sözlük taraması sonucunda ulaşılan atasözleri ile deyimler anlamlarına göre kategorilere ayrılmış ve içerik analizi yöntemiyle incelenmiştir. Çalışmanın sonuç bölümünde bulgular yorumlanmış ve ileriki çalışmalar için öneriler sunulmuştur.

Anahtar Kelimeler: Beden, Kültür, Beden Araştırmaları, Atasözü, Deyim

Atıf: Gürel, E. ve Tat, M. (2019). “Türkçede Beden Olgusu: Atasözleri ve Deyimler Üzerine Bir İçerik Analizi”. Akdeniz Üniversitesi İletișim Fakültesi Dergisi, (AKiL) Aralık (32), s. 235-256

1 Prof. Dr., Ege Üniversitesi, İletişim Fakültesi Halkla Illişkiler ve Tanıtım Bölümü, emet.gurel@ege.edu.tr, ORCID Numarası: 0000-0002-5120-8042

2 Dr. Öğretim Üyesi, Yaşar Üniversitesi, Meslek Yüksekokulu Halkla Ilişkiler ve Tanıtım Programı, merba.tat@ yasar.edu.tr, ORCID Numarası: 0000- 0001-5865-9703 


\title{
The Body Fact in Turkish Language: A Content Analysis on Proverbs and Idioms
}

\begin{abstract}
The body is both the carrier of physiological human existence, and of sociocultural values and beliefs. The body is a concern for various disciplines in the modern world, and is also an important subject of linguistics and cultural studies. Language, one of the main elements constituting the culture of a society, enables the accumulation of experiences and their transfer to future generations. Proverbs and idioms are linguistic tools enhancing expressive power and revealing of the lifestyle, tendencies, beliefs, traditions, and values of a culture. Through studies of proverbs and idioms, the importance and value that society attributes to certain incidents, cases, and situations can be analyzed. This study aims to examine the fact of the body in Turkish proverbs and idioms. The Turkish Language Association's Dictionary of Proverbs and Idioms was selected as the research population and screened, then proverbs and idioms were categorized based on their meaning and reviewed using the content analysis method. The findings are interpreted, and suggestions are made for further studies.
\end{abstract}

Keywords: Body, Culture, Body Studies, Proverb, Idiom

\section{Giriș}

Beden, canlı varlıkların maddesel yönüdür. Canlılar; bedenleri aracılığıyla var olmakta, algılanır ve görünür hale gelmektedir. Beden, insan için de önemli bir belirteçtir. Bedeni ile özdeş olan insan, 'ben' hissiyatını bedeni üzerinden yaşamakta ve kendini bedeni üzerinden konumlamaktadır. İnsan, bir deneyim ve etkileşim aracı olan bedeni ile dış dünyayı algılamakta ve deneyimlemektedir.

Felsefe tarihinde bedene çağlar boyunca 'ruh/beden' ve 'akı//beden' karşıtlıkları temelinde yaklaşılmıştır. 20. yüzyılda ise, bedenin zihinle bir bütün olduğu ve toplumsal yanının olduğu görüşü benimsenmiştir. Beden, yalnızca insana ait bir olgu değildir; toplumun dışında var olan, yalnızca fiziksel bir olgu da değildir. Bedenlerimiz bizim toplumsal deneyimlerimizden olduğu kadar, ait olduğumuz grubun normları ve değerleri tarafından da derinlemesine etkilenmektedir. Giddens'a göre (2000: s. 126) toplum yapısı ve beden arasındaki bağlantının ciddiyeti, bedenin sosyoloji bilimi açısından önemli bir kavram olmasını sağlamaktadır. İçinde bulunduğu kültür ile etkileşim halinde olan, kültürü meydana getirip değiştirebilen ve kültürü oluşturan unsurlardan etkilenen beden; bugün dilbilimin, sosyal ve kültürel analizin temel inceleme alanlarından biridir.

İnsan bedeni var olduğu toplumsal yapının norm, gelenek, inanç ve değerler gibi kültürel unsurlarından etkilenmektedir. İnsanı anlamak için önemli bir çıkış noktası olan beden, kültüre ilişkin birçok ipucu da barındırmaktadır. Her kültür, kendine özgü bir nitelik arz eden ve geçmişten bugüne getirdiği bedensel bir imgeleme sahiptir. Bir kültürün beden olgusuna bakışını anlamak; o kültürün insani var oluşu, bireyselleşme süreci, toplumsal yaşantısı, güce atfettiği önem, cinsiyet rolleri ve iletişim biçimi gibi birçok yönelimini yorumlama konusunda yardımcıdır. 


\section{1. İnsan, Beden ve Beden Araștırmaları}

\section{"Insan bedeni, ruhunun resmidir." \\ Ludwig Wittgenstein}

Beden, insanın uzantısı ve dış dünyaya yönelik ifade formudur. Belki de bu nedenle insanı 'insan' kılan en önemli yönüdür. 1980'li yıllardan itibaren 'beden' konusuna artan akademik ilgi, beden olgusunun farklı terminolojilerle tanımlanması sonucunu doğurmuştur. Beden olgusunun kapsamına, disiplinlerarası niteliğine ve tarihsel gelişimine işaret etmesi nedeniyle; çalışmanın bu bölümünde beden ile ilgili tanımlara, felsefi ve sosyolojik görüş ile yaklaşımlara yer verilmiştir.

Biyolojik bir organizma olarak beden; bir birey ya da hayvanı oluşturan tüm unsurları içeren fiziksel yapı; sistemler içinde çalışan organlardan oluşmuş hücreler topluluğu olarak tanımlanabilmektedir (Cambridge Dictionary, 2019; Lexico's Dictionary \& Thesaurus, 2019; Demello, 2014: s. 5). Etymology Dictionary'e göre beden -body-kelimesi; eski İngilizce 'bodig' kelimesinden gelmektedir ve bir insan ya da hayvanın gövdesi, bir insan ya da hayvanın fiziksel yapısı, bir insanın maddi varlığı ve bir şeyin ana parçası gibi anlamlara gelmektedir (Harper, 2019). Fiziksel niteliği ile beden; nesneleri, çevreyi ve olayları algılama aracıdır. Mekan ve zaman algısı, farkındalık bedenin fonksiyonlarıdır (Richardson ve Locks, 2014: s. 1-5). İnsan eyleminin ve gücünün yegane kaynağı olan beden, bilincin ve deneyimin fiziksel taşıyıcısıdır (Henry, 1975: s. 60).

Beden, Türkçede de çeşitli anlamlara sahip olan bir sözcüktür. Türk Dil Kurumu Büyük Türkçe Sözlük (2019), 'beden' ile ilgili dört tanım vermektedir: “1. Canlı varlıkların maddi bölümü, vücut. 2. Vücudun baş, kol ve bacak dışında kalan bölümü, gövde. 3 . Giysilerde ölçü. 4. Kale duvarı". Tüm bu tanımlar incelendiğinde, Türkçede bedenin birincil anlamına ek olarak yan anlamlara sahip olduğu görülmektedir. Öyle ki Türkçede beden, canlı varlıkların vücudunu ifade eden anlamına ek olarak gövde, giysilerde ölçü ve kale duvarı gibi farklı anlamlarla da karşılık bulmaktadır.

İnsana ilişkin en temel somutlaştırıcı faktör olan beden, temelde felsefi bir kavramdır. Beden, felsefi olarak da, tıpkı dilde olduğu gibi çeşitli anlamlara sahiptir. Akarsu (1975: s. 25), beden ile ilgili beş anlam vermektedir: "1. -Eski Yunan felsefesinde- İnsan ruhunu bu dünyadaki yaşamı sırasında içinde tutsaklayan canlı varlık. 2. -Aristoteles'teRuhun etki araç ve aygıtı. 3. -Descartes'te- Ruhun yanı sıra insanın başka bir bağımsız kurucu öğesi. 4. Ruhsal yaşamın doğal temeli. 5. Yaşamın görünen somut biçimi”. Hançerlioğlu'na (1994: s. 142-143) göre ise "beden, insanın özdeksel yapısıdır. Beden, insanın ruhsal yapısını dile getiren 'ruh' karşılığında kullanılmaktadır. Düşünce tarihinde bu iki kavram karşıtlaştırılmış ve üstünlük düşüncecilerce ruha, özdekçilerce bedene yakıştırılmıştır”.

Beden olgusu popülerliğini çağcıl dönemde kazanmış olsa da ve beden araştırmaları bir kavramlaştırma alanı olarak yakın dönemle tarihlense de, beden düşünce tarihinde üzerinde en çok durulan konular arasındadır. Hançerlioğlu'nun (1994) da işaret ettiği üzere beden ve ruh karşıtlığı en çok işlenen temalar arasındadır. Doğu felsefesinde be- 
den, ruha kıyasla ikincil önemdedir. Batı felsefesinde ise bedeni kutsayan yaklaşımların yanı sıra ruha bedene kıyasla daha fazla önem atfeden görüşler bulunmaktadır.

Batı felsefe tarihinde, özellikle Antik dönemde ve Ortaçağ'da ruh-beden dualizmi yoğun olarak işlenmiştir. Antik Yunan'da bedeni kutsayan düşünürlerin varlığına rağmen; Sokrates, Protagoras ve Platon madde ötesi boyut ve ruha öncelik vermiş; Aristoteles, Demokritos gibi düşünürler de beden -madde- ve ruha eşit önem yüklemiştir (Lange, 2001; Kaya, 2013: s. 177). Ortaçağ Hristiyanlık anlayışında beden, Tanrı'nın yeryüzündeki bir yansıması olarak değerlendirilmiş olup disipline edilmediğinde kötülüklerin kaynağı olarak görülmüştür. Bu yönüyle beden, hem Tanrı'ya yakın olmanın yolu hem de Tanrı'ya ulaşmaya yönelik bir engel olarak yorumlanmıştır.

17. yüzyılda Hristiyanlıktaki karşıtıı içeren bu bakış açısı değişmeye başlamıştır. Bilim ve tıpta yaşanan gelişmelerle bedenin fiziksel sağlığını artırma çabaları baş göstermiş ve bu durum da Hıristiyanlık inancındaki günahlardan arınması için acı çekmesi gereken beden algısını değiştirmiştir (T. Demir, 2018: s. 314-315). Kutsal Kitaba sahip diğer dinlerde -Yahudilik ve Müslümanlık-, ruh ve beden birbirlerinin tamamlayıcısı olarak kabul edilmiştir. Yahudilik inancında, Tanrı'ya ait olan beden korunmalı ve sağlığına dikkat edilmelidir. Yahudilik, ruh ve beden ayrımını kabul etmemekte, ikisini bir bütün olarak görmektedir. İslamiyet ise bedeni, insanoğluna verilmiş bir emanet olarak nitelemektedir. İslam inancı beden ve ruh sağlığı açısından insana fayda verecek şeyleri teşvik ederken, zarar verecek şeyleri yasaklamaktadır (İmamoğlu, 1995: s. 348; Başak, 2016: s. 484; Bayram vd., 2019: s. 207).

Batı düşünce tarihi, bedene yönelik bakış açısının değişiminde önemli bir kilometre taşıdır. Bu bağlamda moderniteyi yaratan ve beden algısının değişimine de aracılık eden üç önemli aşamadan söz etmek mümkündür: 'Aydınlanma Felsefesi', 'Fransız Devrimi' ve 'Sanayi -Endüstri- Devrimi' (Duman, 2010: s. 15). Rasyonalizmi temel alan Aydınlanma Felsefesi, bedeni aklın karşısına yerleştirmiştir. Modern felsefenin kurucusu kabul edilen René Descartes'e göre beden, zihinden bağımsızdır. Öyle ki Descartes, 'düşünüyorum, o halde varım' önermesi ile aklı öncelemiştir (Ketenci, 2014: s. 66; Kalelioğlu, 2018: s. 3). 18. yüzyıla damga vuran ve yenilikçi akımları beraberinde getiren Fransız İhtilali, beden olgusunun kamusal niteliği ve öneminde büyük değişiklik yaratmıştır. Devrimde orta sınıfa ilişkin kamusal alanın yeniden yaratıldığını ileri sürmek mümkündür. Bu alan, yüzyıllar boyunca 'kralın beden imajı' tarafından tanımlanırken, kitle politikası için kahramansı nitelikler atfedilen yeni bedenler oluşturulmuştur (Outram, 1989: s. 2-4). Değişimi ve ilerlemeyi kural haline getiren Sanayi Devrimi ile birlikte metafizik ile ilişkili her şey reddedilmiş, bilimsel bilgi ön plana çıkmış; teknolojik, sosyo-ekonomik ve kültürel alanlarda değişim yaşanmıştır. İnsanların örnek alması gereken beden biçimlerinin ortaya konduğu bu dönemde Oskay'a (2004: s. 152-153) göre "moda, kozmetik ve tıp; insanları belli bir formun güzel olduğuna ve o formu korumaya çalışmazsa toplumdan dışlanabileceğine telkin etmeye başlamıştır".

Beden; felsefenin olduğu kadar, sosyolojinin de ilgi alanına giren bir olgudur. Kültürün ve kültürel kimliğin ifade bulduğu; kültürel söylem ile semiyolojik dizgeler ve sembolik ifadelerin taşıyıcısı olarak okunabilecek bir metin özelliği gösteren beden aynı zamanda kültürü oluşturmakta, biçimlendirmekte ve sürdürmektedir. Toplumları oluşturan bi- 
reyler bedenleriyle iletişime girerek kültürün oluşumunda, değişiminde ve aktarımında rol oynamaktadır. İnsan bedeninin iletişim yetisi; bilginin, deneyimlerin, değerlerin, inançların ve normların nesilden nesile aktarılmasını sağlamaktadır. Bu yönüyle beden, toplumların kültür çevrimini sürekli kılmaktadır.

Sosyoloji tarihine bakıldığında bedenin, başlangıçtan itibaren bir inceleme konusu olduğu görülebilmektedir. Bu bağlamda klasik sosyoloji kuramcılarının temel analiz noktası, modernleşme ve farklılaşan toplumsal değerlerdir. 19. yüzyılın önemli düşünürlerinden bazıları bedeni ön plana çıkarırken, bazıları da ruh ve bedeni iki ayrı öz olarak ele almaya devam etmiştir. Emile Durkheim, Auguste Comte, Karl Marx, George Simmel ve Max Weber; beden üzerine savlar üreten düşünürlerden bazılarıdır.

Ruh-beden düalizmini benimseyen Durkheim için, ruh ve beden birbirinden bağımsız olan ve birbiriyle çatışan iki farklı yapıdır. Öyle ki insanlar, bu dünyaya ait bir bedene ve kutsal bir ruha sahiplerdir. Bedenin toplumun temelinde yer aldığına inanan Durkheim, insanın bedensel yönünü, bedensel arzu ve dürtülerin egemen olduğu egoistik 'bireysel beden' ve toplumsal kategoriler ile duyulara göre biçimlenen 'toplumsal beden' olmak üzere ikiye ayırmıştır. Toplumsal olgunlaşma sürecinde, egoistik yan toplumsal ve ahlaki gerekliliklere göre ikincilleşmektedir. Başka bir ifadeyle, 'bireysel beden', 'toplumsal bedene' dönüşmektedir. Ona göre insan; içgüdü, istek ile algılarından oluşan bir bedensel varlığa ve kendini geliştirme kapasitesine sahiptir. İnsanın bencil yönü, toplumsal ve ahlaki yönü tarafından kontrol altına alınmaktadır. Bu yolla sosyal bedenin, bireysel bedeni değiştirdiğini ifade etmek mümkündür (Durkheim, 2005: s. 36; Shilling 2005: s. 1-19; Nazlı, 2009: s. 62).

Sosyoloji tarihinin bir diğer duayen ismi olan August Comte ise, dualizm düşüncesini eleştirmiştir. Comte'un Pozitivist felsefesinde metafizik olguların uygulamada yeri yoktur. Bilim, olayların somut yönünde odaklanmalıdır. Comte, ruh-beden ikiliğinin beden -madde- yönünü kabul etmiştir (Hira, 2000: s. 84).

Beden olgusunu kapitalist toplumda çalışan beden üzerinden değerlendiren Karl Marx bedeni Yabancılaşma Kuramı çerçevesinde ele almıştır. Ona göre insan, kapitalist toplumda kendine ve emeğine yabancılaşmaktadır. Modern sanayide insan makinenin bir parçasıdır. Bu durum bedeninin potansiyelini ortaya koyma ve kendini gerçekleştirme noktasında insana engel olmakta ve kendisine yabancılaşması sonucunu doğurmaktadır (Z. Demir, 2018: s. 65).

Georg Simmel, bedenin toplumun meydana gelmesinde ve sürekliliğinde rolü olduğunu ifade etmektedir. Simmel'e göre toplum, bireylerin çeşitli amaçlara ulaşmak için etkileşim kurmasıyla oluşmaktadır. Söz konusu amaçlar, insanların diğerleriyle arasında bir bağ kurmasını sağlamaktadır. Birbiriyle etkileşime giren bireyler, 'birlik' oluşturmaktadır. Bu etkileşimin kurulma aracı ise, doğrudan insan bedenidir. Bedenler etkileşime temel oluşturabildikleri gibi, etkileşim biçimleri de bedenler üzerinde etki yapma potansiyeline sahiptir (Çil, 2017: s. 460).

Beden sosyolojisinin kuramsal gelişimine katkı koyan Max Weber ise bedeni, rasyonelleşme ve kapitalizm ile din sosyolojisi çerçevesinde konu etmiştir. Weber'e göre Hristiyanlık dini mezheplerinden Protestanlığın aklı bedenden üstün tutan 
yaklaşımı, bedeni rasyonalize etmektedir. Bu bağlamda, Tanrıya hizmet edebilmek için çok çalışıp üretimde bulunulmalı, rasyonellikle çelişen dünyevi zevklerden uzak kalınmalıdır. İnsanoğlunun ruhsal kurtuluşa erebilmek için kendini çalışmaya adaması, kapitalizmin temel mantığına paralel bir yaklaşımdır (Weber, 2012).

20. yüzyıla gelindiğinde, özellikle 1920 ve 1930'larda bedenin etnolojik yanının olduğunun kabul görmeye başlamasıyla bedeni merkeze alan ilk araştırmalar gerçekleştirilmiştir. İnsan bedeninin içinde bulunduğu kültürel yapı içinde incelenmeye başlaması ile birlikte sosyolojinin bir alt dalı olan 'beden sosyolojisi' gündeme gelmiştir. Beden sosyolojisi -sociology of body-, en yalın ifadeyle bedenin toplum ve toplumsal etmenler tarafından nasıl etkilendiğini araştıran sosyoloji alanıdır. Beden sosyolojisi; insanları salt değerleri ve tutumları olan aktörler değil, aynı zamanda cisimleşmiş kişiler olarak analiz etmektedir. Bu doğrultuda bedenlere atfedilen değişik kültürel anlamları, hastalığa ve cinselliğe de özel bir önem vererek bunların denetlenme, düzenlenme ve yeniden üretilme biçimlerini de irdelemektedir (Marshall, 1999: s. 62).

Görece yeni bir uzmanlık alanı olan beden sosyolojisi; bedenin toplumsal niteliği, toplumsal temsili, konumu ve fonksiyonları ile bedensel değişim gibi konuları kapsamaktadır (Eichberg, 2009: s. 80). Beden sosyolojisinin bir çalışma alanı olarak kabul görmesinde, Michel Foucault'un etkisi büyüktür. Bedene karşıtlıklar üzerinden yaklaşan düalist ayrımları eleştiren Foucault, 1960'larda gerçekleştirdiği beden konusundaki kapsamlı çalışmalarıyla tanınmaktadır.

Beden, Foucault'un 1964 yılında yayınlanan Naissance de la Clinique -Kliniğin Doğuşuadlı eserinin temel akslarından birini teşkil etmiştir. Foucault, bu eserinde modern tıbbın doğuşuyla tıbbın sosyal, söylemsel ve bilgiye dayalı -epistemikkoşullarının yeniden örgütlenmesi arasında nasıl bir ilişki kurulabileceğini tartışmıştır (Potte-Bonneville, 2012: s. 7-8). Geliştirdiği ‘Biyopolitika Kuramı’ ile iktidarın bedenler üzerindeki kontrolünü ele alan Foucault (2000: s. 137); birey üzerindeki toplumsal kontrolün beden yoluyla sağlandığını, bedenin biyopolitik bir gerçeklik, tıbbın ise biyopolitik bir strateji olduğunu savunmuştur.

20. yüzyılda beden sosyolojisi alanında çalışan sosyologların önemli bölümünün, beden ile ilgili düalist ayrımları eleştirdiğini söylemek mümkündür. Bu anlamda, Foucault ile paralel anlayışa sahip olan düşünürlerden Pierre Bourdieu'ya göre modern toplumlarda metalaşmış olan beden bir sembolik değer taşıyıcısıdır. Beden; barındırdığı ayırdedici sembolik biçimler, statü ve güçle bir fiziksel sermaye biçimidir (Shilling, 1993). Birey ve toplumun birbirini nasıl etkilediğini açıklayan Bourdieu'nun içselleştirilmiş yatkınlıklar olarak ifade bulan 'habitus' vurgusunda, bireylerin davranışlarında yaşadıkları toplumun kültürel etkileri vardır. Diğer bir ifadeyle bireyler özgür seçim yaptıklarını sansa da, aslında zihinsel yatkınlıkları seçimlerini etkilemektedir. Davranışlara bir karakter kazandıran habitus, bedende cisimleşmektedir. İtibar arayışının odak noktası bireyin bedenidir. Beğeni, her sınıfın kendi beden tasavvurunu belirlemektedir. Beğenideki farklılıklar da; bedenin güzellik, sağlık ve dayanıkılığı hakkındaki izlenimleri belirlemektedir (Palabıyık, 2011: s. 128-131; Dikkol, 2016: s. 4).

Akıl ya da ruhu bedenin karşısına koyan düşünceye karşı çıkan diğer bir düşünür Maurice Merleau Ponty ise, bedeni fiziksel objeler içinde bir nesne olarak kabul eden 
bakışa karşı çıkmaktadır. Ona göre, düşünce ve beden bir bütündür. Bedenin dünya ile ilişkisini ele alan Ponty, bedensel yönelim ve aktivitelerimizin dünyayı insanoğlu için anlaşılır kıldığına dikkat çekmektedir. Bedensel deneyimlerimiz dünyayı anlamamızı sağlamaktadır, bedenimizi nasıl deneyimlediğimiz dünyanın bizden talep ettiği devinim ve faaliyetlerle şekillenmektedir. Beden ve dünya arasındaki ilişki, dinamik ve süreçsel bir oluşdur (Cimini, 2012: s. 355).

Düalist kavrayışı eleştiren diğer düşünür Jean Baudrillard (1998: s. 129) ise, postmodern dönemde bedenin tüketim kültüründe önemli bir rolü olduğunu ifade etmektedir. Beden, fiziksel ve cinsel özgürleşme ruhuyla yeniden keşfedilmektedir. Özellikle kadın bedeninin çevresini sarmalayan gençlik, güzellik, dirilik, formda olmak takıntıları ile reklamcılık sektörü, moda sektörü ve kitle iletişimindeki sık görünümü ile beden bir kurtuluş nesnesi haline gelmiştir. Beden, ruhun ahlaki ve ideolojik işlevini eline geçirmiştir. Beden, kültürel bir gerçektir. Bugün her kültürde bedenle olan ilişkinin örgütlenme şekli nesnelerle ve sosyal ilişkilerle olan ilişkinin örgütlenme biçimini yansıtmaktadır.

Beden; felsefi ve sosyolojik olduğu kadar, iletişimsel bir olgudur. İletişimsel perspektifte beden, insanın duygu ve düşüncelerini diğer insanlara aktaran bir araçtır. Bu bağlamda "beden dili -body language-; mesajların jest, duruş biçimi, uzamsal ilişkiler vb. ile iletildiği sözsüz bir iletişim biçimidir” (Mutlu, 2004: s. 39). Beden ve beden hareketleri, bilgi veren ve bilgi taşıyan birer araçtır. Bununla birlikte beden dili ile ilgili kitapların büyük çoğunluğu genelde bilimsel araştırmalar üzerine kurulmamıştır ve -eğer okunacaklarsa bile- sağlıkı bir kuşkuculukla okunmalıdırlar. Hiç kimse güvenilir bir beden hareketleri sözlüğü yazamamıştır. Beden hareketlerinin anlamı bağlam, eylemde bulunan kişi ve kültür gibi bir çok etmene bağlıdır (Freedman vd., 2003: s. 124).

Literatür taramasının da ortaya koyduğu üzere beden; günümüzde sosyoloji ve felsefe disiplinlerinin yanı sıra dil, din, psikoloji, tarih, antropoloji, tıp, çevre, yönetim, siyaset, eğitim, iletişim, ekonomi, güzel sanatlar, spor gibi birçok disiplinin uğraşı kapsamındadır. Beden ile ilgili araştırmaları, 'beden araştırmaları' adı altında kavramlaştırmak mümkündür. Disiplinlerarası nitelik arz eden beden araştırmalarına olan ilgi teknoloji, toplum ve beden arasındaki ilişkinin uğradığı köklü değişimle artmaya ve çeşitlenmeye devam etmektedir (Turner, 2012).

\section{Araștırmanın Amacı ve Önemi}

Bir kültür araştırması ve atasözü-deyim araştırması olarak nitelenebilecek bu çalışma kapsamında literatür bölümünde konu edilen tanımlama ve saptamalardan hareket ederek beden olgusunun Türk kültüründeki yerini atasözleri ve deyimler aracılığıyla araştırmak amaçlanmıştır. Diğer bir ifadeyle çalışma, atasözü ve deyim araştırmaları üzerinden beden araştırması gerçekleştirmeyi hedeflemektedir.

Beden gibi, atasözleri ve deyimler de; bir toplum ve kültür hakkında ipuçları barındıran unsurlardır. Dilbilim ve halkbilimin üzerinde en çok çalışılan araştırma konuları arasında yer alan atasözleri ve deyimler; bir toplumun geçmişi ve yaşam biçimini anlatan yapılardır. Bir kültürün düşünüş tarzını, evren algısını, yaşam felsefesini, inançlarını, deneyim ve geleneklerini atasözü ve deyimler üzerinden analiz etmek mümkündür. 
Bu gerçekten hareketle, çalışma kapsamında Türk kültüründe bedene verilen önemi ve beden hakkındaki kültürel yönelimleri ortaya koyabilmek amacıyla Türk Dil Kurumu Atasözleri ve Deyimler Sözlüğü'nde beden ile ilgili atasözü ve deyimler araştırılmıştır. Ulaşılan atasözleri ve deyimler oluşturulan kategoriler aracılığıyla içerik analizine tabi tutulmuş, bulgular yorumlanmış ve araştırmanın sonuç kısmında değerlendirilmiştir. Çalışmanın Türk toplumunun bedene bakış açısını ortaya koymak ve beden çalışmaları çerçevesinde Türk kültürüne özgü bir saptama yapmak açısından önemli olduğu düşünülmektedir.

Türkçede beden olgusunu analiz etmeye yönelik olan bu araştırmanın soruları, araştırmanın amaç ve öneminden hareketle şu şekilde oluşturulmuştur:

- Türkçede beden olgusu atasözü ve deyimlerde ne şekilde ele alınmaktadır?

- Türk kültüründe beden olgusunun yeri ve önemi nedir?

\section{Yöntem}

Nitel araştırma yaklaşımı doğrultusunda tasarlanan çalışmanın evrenini, Türk Dil Kurumu'nun hazırladığı 'Atasözleri ve Deyimler Sözlüğü' oluşturmaktadır. Bu sözlük; geniş ve kapsamlı bir veri tabanına sahip olması, akademik nitelikli olması ve temsiliyet potansiyelinin güçlü olması nedeniyle seçilmiştir. Araştırma kapsamında nitel araştırma örnekleme yöntemlerinden kriter örnekleme ile belirlenen atasözleri ve deyimler, anlamlarına göre kategorilere ayrılmış ve içerik analizi yöntemi ile incelenmiştir.

İçerik analizi -content analysis-; sosyal gerçekliğin açık özelliklerinden mesaj ve kaynağa yönelik açık olmayan özellikler hakkında çıkarımlar yapılmasını mümkün kılan bilimsel bir araştırma tekniğidir. Çeşitli metinlerden yinelenebilir ve geçerli anlam çıkarımına olanak tanıyan içerik analizi; yazılı malzemenin, imajların, sesin, işaretlerin, sembollerin ve sayısal kayıtların veri olarak çözümlenmesinde kullanılabilmektedir. Sosyal gerçekliği araştırmada yararlanılan teknik, gazetecilik ve kitle iletişimi temelli olsa da siyaset, sosyoloji, psikoloji, psikiyatri, tarih, antropoloji, eğitim, dinbilim, tarih, filoloji ve dilbilim alanlarında metin analizine olanak tanımaktadır (Krippendorf, 2004: s. 1-7).

\section{Bulgular ve Değerlendirme}

Araştırma kapsamında 'beden' ve 'vücut' kelimeleri TDK Atasözleri ve Deyimler Sözlüğü’nde, atasözü/deyim ve anlam temelinde taranmıştır. Söz konusu sözlüğe, resmi web sitesi üzerinden erişebilmek ve arama yapabilmek mümkündür. Mart 2019'da gerçekleştirilen tarama sonrasında elde edilen bulgular derlenerek 'atasözü' ile 'deyim' şeklinde kategorize edilmiş ve alfabetik düzene uygun olarak dizilmiştir. Tablo. 1.'de Türkçede bulunan beden ile ilgili atasözleri ile deyimler toplu olarak sunulmuştur. 
Tablo 1. Türkçede Bulunan ‘Beden’ Ile İlgili Atasözleri ve Deyimler

\begin{tabular}{|c|c|}
\hline Atasözü & Deyim \\
\hline $\begin{array}{l}\text { - Ağaca balta vurmuşlar, sapı bedenimden demiş } \\
\text { - Baş sağlığı, dünya varlığı } \\
\text { - Başın sağlığı, dünyanın varlığı } \\
\text { - Boyuma göre -boyumca- boy buldum, huyuma göre } \\
\text { - huyumca- huy bulmadım } \\
\text { - Her işin -şeyin- başı sağlık } \\
\text { - Kalıp kıyafetle adam adam olmaz }\end{array}$ & $\begin{array}{l}\text { - Ateşi çıkmak -yükselmek- } \\
\text { - Ateşini almak } \\
\text { - -Birinin- tüyleri diken diken olmak } \\
\text { - Dal gibi } \\
\text { - Dişarı atmak } \\
\text { - Doping yapmak } \\
\text { - Eli ayağı tutmak } \\
\text { - Esen kalmak } \\
\text { - Filiz gibi } \\
\text { - Hararet basmak } \\
\text { - Heykel gibi } \\
\text { - Idman yapmak } \\
\text { - Kafası ile oynamak } \\
\text { - Kan kaybetmek } \\
\text { - Kapı gibi } \\
\text { - Kendini yoklamak } \\
\text { - Kulunç girmek } \\
\text { - Kum dökmek } \\
\text { - Manken gibi } \\
\text { - Nefsine uymak } \\
\text { - Nefsini köreltmek -körletmek- } \\
\text { - Ot tutunmak } \\
\text { - Ölçü almak } \\
\text { - Taş kırdırmak } \\
\text { - Taş düşürmek } \\
\text { - Taşı sıksa suyunu çıkarır } \\
\text { - Topaç gibi } \\
\text { - Tek vücut olmak } \\
\text { - Vücuda gelmek } \\
\text { - Vücuda getirmek } \\
\text { - Vücudunu ortadan kaldırmak } \\
\text { - Vücut bulmak } \\
\text { - Vücut kocar, gönül kocamaz } \\
\text { - Vücut vermek } \\
\text { - Vücut yapmak } \\
\text { - Vücuttan düşmek } \\
\text { - Yara açmak } \\
\text { - Yumruğuna güvenmek }\end{array}$ \\
\hline
\end{tabular}

Türkçede bulunan 'beden' ile ilgili atasözleri ve deyimler incelendiğinde, atasözlerinin nicelik olarak deyimlere kıyasla azınlıkta olduğu görülmüştür. Bulgular uyarınca Türkçede beden ile ilgili atasözleri ve deyimlerin varlığı ile deyimlerin sayısal çokluğunun, Türk kültüründe bedene önem verilmesi ile bağlantılı olduğunu ifade etmek mümkündür.

Araştırma bulguları; 'beden ve oluşum', 'beden ve sağlık', 'beden ve spor', 'beden ve özyönetim', 'bedensel nitelikler', 'beden bakımı', 'beden, ilişki ve iletişim' ile 'beden ve giyinmek' kategorileri üzerinden ele alınmıştır. Kategoriler, araştırmacılar tarafından bizzat oluşturulmuştur. 


\subsection{Beden ve Olușum İle İlgili Atasözleri ve Deyimler}

Beden; insanın ve yaşamın görünen, diğer bir deyişle somut biçimidir. Bu bağlamda beden, oluşum kavramına eşdeğer bir anlam arz etmektedir. Oluşum, bedenlenmek ve belirli bir varlık kazanmak demektir.

Gerçekleştirilen araştırma kapsamında, Türkçede bedenin somutlaşma, oluşma, varlık kazanma amacına gönderme yapan deyimlerin varlığı tespit edilmiştir. Kategoriye ilişkin atasözü bulgulanamamıştır. Söz konusu bulgular, Tablo. 2.'de sunulmuştur.

Tablo 2. Beden ve Oluşum İle İlgili Türkçede Bulunan Atasözleri ve Deyimler

\begin{tabular}{|c|l|}
\hline Atasözü & \multicolumn{1}{c|}{ Deyim } \\
\hline & • Vücuda gelmek \\
& • Vücuda getirmek \\
& - Vücudunu ortadan kaldırmak \\
& - Vücut bulmak \\
& • Vücut vermek \\
\hline
\end{tabular}

Kategori uyarınca beden ve oluşum ile ilgili beş deyimin mevcut olduğu görülmüştür. Bu deyimlerden dört tanesi olumlu, bir tanesi olumsuz niteliktedir. Diğer bir ifadeyle kategori kapsamında bulgulanan dört deyim oluşum, bir deyim ise oluşumun ortadan kalkması anlamını ifade etmektedir.

'Vücuda gelmek', 'vücuda getirmek', 'vücut bulmak' ve 'vücut vermek' deyimleri kategori kapsamındaki olumlu anlama sahip olan deyimlerdir. Bu bağlamda 'vücuda gelmek' deyimi; ortaya çıkmak, oluşmak, meydana gelmek ve olmak demektir. 'Vücuda getirmek' deyimi, meydana getirmek ve var etmek olarak karşılık bulmaktadır. 'Vücut bulmak' deyimi, oluşmak anlamına gelmektedir. 'Vücut vermek' deyimi ise, vücuda getirmek olarak karşılık bulmaktadır.

'Vücudunu ortadan kaldırmak' deyimi, kategori kapsamındaki olumsuz anlama sahip olan deyimdir. Bu deyim, öldürmek olarak ifade bulmaktadır.

\subsection{Beden ve Sağlık İle İlgili Atasözleri ve Deyimler}

Sağlık -health-, vücudun hasta olmaması durumudur. Diğer bir ifadeyle vücudun esenliği ve sıhhatidir. Bu bağlamda gerçekleştirilen araştırma kapsamında, Türkçede beden ve sağlık ile ilgili atasözleri ve deyimlerin varlığı tespit edilmiştir. Bu bulgunun kökeninde, sağlığın vücut üzerinden ifade bulan bir durum olmasının yattığını ileri sürmek mümkündür.

Gerçekleştirilen araştırma uyarınca Türkçede beden ve sağılı ile ilgili atasözleri ve deyimlerin var olduğu tespit edilmiştir. Söz konusu atasözleri ve deyimler, Tablo. 3.'te sunulmuştur. 
Tablo 3. Beden ve Sağlık İle İlgili Türkçede Bulunan Atasözleri ve Deyimler

\begin{tabular}{|c|c|}
\hline Atasözü & Deyim \\
\hline $\begin{array}{l}\text { - Baş sağlığı, dünya varlığı } \\
\text { • Başın sağlığı, dünyanın varlığı } \\
\text { • Her işin -şeyin- başı sağlık }\end{array}$ & $\begin{array}{l}\text { - Ateşi çıkmak -yükselmek- } \\
\text { - Ateşini almak } \\
\text { - -Birinin- tüyleri diken diken olmak } \\
\text { - Dışarı atmak } \\
\text { - Eli ayağı tutmak } \\
\text { - Esen kalmak } \\
\text { - Hararet basmak } \\
\text { - Kan kaybetmek } \\
\text { - Kulunç girmek } \\
\text { - Kum dökmek } \\
\text { - Taş kırdırmak } \\
\text { - Taş düşürmek } \\
\text { - Yara açmak } \\
\text { - Vücut kocar, gönül kocamaz } \\
\text { - Vücuttan düşmek }\end{array}$ \\
\hline
\end{tabular}

Araştırma kapsamında, Türkçede 'beden ve sağlık' ile ilgili deyimlerin, atasözlerine kıyasla daha fazla olduğu görülmüştür. Kategoriye ilişkin, üç atasözü ve on beş deyim bulunmaktadır.

Atasözleri kategorisi incelendiğinde, beden ile ilgili atasözlerinin beden sağlığına vurgu yaptıkları görülebilmektedir. Dolayısıyla Türk toplumunun, beden sağlığını her şeyden daha fazla önemsediği ve tüm servetlerin üzerinde tuttuğu yorumunu yapmak mümkündür. Bu bağlamda 'baş sağlığı, dünya varlığı' ve 'başın sağlığı, dünyanın varlığı' atasözleri, en büyük zenginliğin beden sağlığı olduğunu ifade etmektedir. 'Her işin -şeyin- başı sağlık' atasözü ise, insanın yapacağı her şeyin vücut sağlığına bağlı olduğu anlamındadır.

Deyim kategorisine göz atıldığında; 'sağlık', 'hastalık' ve 'yaşlılık' hallerine gönderme yapan deyimlerin var olduğu görülebilmektedir. Alt kategoriler kapsamında hastalık haline gönderme yapan deyimler, sağlık haline gönderme yapan deyimlere kıyasla niceliksel olarak fazladır. Bu bağlamda sağlık hali ile ilgili iki deyim, hastalık hali ile ilgili on iki deyim, yaşlılık hali ile ilgili bir deyim bulunmaktadır.

'Eli ayağı tutmak' ve 'esen kalmak' deyimleri, sağlık ile ilgilidir. 'Eli ayağı tutmak', beden gücü yerinde olmak anlamındayken; 'esen kalmak', ruhsal ve bedensel olarak sağlıklı, sıhhatli olmak olarak ifade bulmaktadır.

'Ateşi çıkmak -yükselmek-', 'ateşini almak', '-birinin- tüyleri diken diken olmak', 'dışarı atmak', 'hararet basmak', 'kan kaybetmek', 'kulunç girmek', 'kum dökmek', 'taş kırdırmak', 'taş düşürmek', 'yara açmak', 'yara yapmak' ve 'vücuttan düşmek' ise hastalık haline işaret eden deyimlerdir. Hastalık haline ilişkin deyimlerin fazlalığı dikkat çekmektedir.

Hastalık hali ile ilgili deyimlere göz atıldığında, vücut ısısının yükselmesi ile ilgili üç deyimin bulunduğu görülmektedir. Söz konusu deyimler; 'ateşi çıkmak selmek-', 'ateşini almak' ve 'hararet basmak' olarak sıralanabilmektedir. Bu kapsamda 'ateşi çıkmak -yükselmek-', vücut ısının olağandan çok artması demektir. Vücut ısısı 
ile ilgili bir diğer deyim olan 'ateşini almak'; yüksek vücut ısısını düşürmek ve derece ile ateşi ölçmek anlamlarının yanı sıra mecaz olarak acıyı, yanmayı azaltmak anlamını taşımaktadır. Vücut ısısı ile ilgili üçüncü deyim olan 'hararet basmak' ise, vücut ısısı artmak demektir.

Hastalık haline ilişkin deyimlerde dikkat çeken bir diğer unsur, böbrek taşları ile ilgilidir. Böbrek taşları ile ilgili, üç deyim bulunmaktadır. 'Kum dökmek', 'taş düşürmek' ve 'taş kırdırmak' söz konusu deyimlerdir. Bu bağlamda 'kum dökmek', idrar yoluyla böbreklerde oluşan kum taneciklerini vücuttan atmak anlamına gelmektedir. 'Taş düşürmek', böbrekte oluşan kum ve taşları vücuttan atmak; 'taş kırdırmak', böbrek taşlarını çeşitli yollarla parçalara ayırarak vücuttan atmak olarak ifade bulmaktadır.

Hastalık hali ile ilgili bir diğer dikkat çeken unsur, kan ile ilgilidir. Yaşamsal vücut sıvısı olan kan ile ilgili bir deyim bulunmaktadır. Bu çerçevede 'kan kaybetmek' deyiminin iki anlamı vardır. Birincil anlam olarak herhangi bir nedenle vücuttan çok kan akmak; mecaz nitelikli ikincil anlam ise güçsüzleşmek, etkisini kaybetmek anlamındadır.

'-Birinin- tüyleri diken diken olmak', 'dışarı atmak', 'kulunç girmek', 'yara açmak' ve 'vücuttan düşmek' kategori kapsamındaki diğer deyimlerdir. '-Birinin- tüyleri diken diken olmak', üşümekten veya korkmaktan vücuttaki kıllarının dipleri kabarıp kılları dikilmek; 'dışarı atmak', zararlı bir maddeyi terleme, idrar ve benzeri yollarla vücuttan çıkarmak; 'kulunç girmek', bir organda veya vücut bölgesinde birdenbire veya şiddetli sancı oluşması, tutulmak olarak ifade bulmaktadır. 'Yara açmak', vücutta yara oluşmasına sebep olmak; 'vücuttan düşmek' ise, zayıflamak demektir.

Kategori kapsamında yaşlılık ile ilgili bir deyim bulgulanmıştır. Bu bağlamda 'vücut kocar, gönül kocamaz' deyimi; kişi intiyarlar ama gönlü taze kalır, sevgisi eksilmez anlamına gelmektedir. Bu bağlamda felsefe tarihi boyunca süregelen beden-ruh ikiliğinin, söz konusu deyim paralelinde ruh temelinde kazanıımış olduğunu ileri sürmek mümkündür.

\subsection{Beden ve Spor İle İlgili Atasözleri ve Deyimler}

Türk Dil Kurumu Büyük Türkçe Sözlük'e (2019) göre spor; kişisel veya toplu yarışlar biçiminde yapılan, bazı kurallara göre uygulanan beden hareketlerinin tümüdür. Spor; insan ve beden olmaksızın yapılması mümkün olmayan, bedenin geliştirilmesini ve sağlıklı kılınmasını sağlayan bir araçtır (Melin, 2013).

Araştırma bulguları uyarınca, beden ve spor ile ilgili Türkçede deyimlerin var olduğu bulgulanmıştır. Kategoriye ilişkin atasözü bulunmamaktadır. Söz konusu bulgular, Tablo. 4.'te sunulmuştur.

Tablo 4. Beden ve Spor İle İlgili Türkçede Bulunan Atasözleri ve Deyimler

\begin{tabular}{|l|l|}
\hline Atasözü & \multicolumn{1}{|c|}{ Deyim } \\
\hline & • Doping yapmak \\
& • Idman yapmak \\
& $\cdot$ Kafası ile oynamak \\
& $\cdot$ Vücut yapmak \\
\hline
\end{tabular}


Araştırma kapsamında, Türkçede beden ve spor ile ilgili dört deyimin mevcut olduğu görülmüştür. Söz konusu deyimlerden iki tanesi beden çalıştırmak, bir tanesi spor esnasında beden yerine kafayı kullanmak, bir tanesi ise bedenin formunu değiştirmek için uyarıcı ilaçlar almak ile ilgilidir.

Bu bağlamda 'idman yapmak' ve 'vücut yapmak' deyimleri, beden hareketleri yapmak ve bu şekilde vücudu güçlendirmek anlamına gelmektedir. 'Kafası ile oynamak' deyimi, takım sporlarında arkadaşlarının durumunu göz önünde tutup en iyi fırsatı değerlendirerek bedenini fazla yormadan oynamak olarak ifade bulmaktadır. 'Doping yapmak' deyimi ise, bazı bedensel özellikleri değiştiren veya artıran bir uyarıcı maddeyi çok az miktarda almak anlamına gelmektedir.

\subsection{Beden ve Özyönetim Ille İlgili Atasözleri ve Deyimler}

Özyönetim -selfmanagement-; kişinin amaç ve beklentilerine kendi içsel potansiyeli ile ulaşabilmesi, başarı odaklı olması, duygularını anlaması ve kontrol edebilmesi, kişisel bütünlük içinde olması, esnek davranabilmesi ve değişime açık olması, engellerden yılmaması gibi yetkinliklerden oluşan kişisel yeterlilikler olarak tanımlanabilmektedir (Jacobs, 2001: s. 165). Özyönetim; bir kültürün üyeleri arasında uyum sağlanmasına, kişilerarası yıkıcı çatışmaların önüne geçilmesine, kişilerarası ilişkilerin gelişiminin önünün açılmasına, diğer kişilerle yapıcı ve etkin iletişim kurulmasına aracılık eden yetkinlikler bütünüdür.

İnsan bedeni aracılığıyla özyönetim yetkinliklerini ortaya koyabilmekte, bu yetkinlikleri geliştirebilmektedir. Özyönetim becerilerinin kişisel gelişimde, toplumsal yaşamda ve iş yaşamında önemli bir rol oynadığını ileri sürmek mümkündür. Araştırma bulguları uyarınca, beden ve özyönetim ile ilgili Türkçede deyimlerin var olduğu bulgulanmıştır. Kategoriye ilişkin atasözü bulunmamaktadır. Söz konusu bulgular, Tablo. 5.'te sunulmuştur.

Tablo 5. Beden ve Özyönetim İle İlgili Türkçede Bulunan Atasözleri ve Deyimler

\begin{tabular}{|l|l|}
\hline Atasözleri & \multicolumn{1}{c|}{ Deyimler } \\
\hline & $\begin{array}{l}\cdot \text { Kendini yoklamak } \\
\cdot \text { Nefsine uymak } \\
\end{array}$ \\
& \\
& \\
\hline
\end{tabular}

Araştırma kapsamında, Türkçede beden ve özyönetim ile ilgili üç deyimin mevcut olduğu görülmüştür. Söz konusu deyimlerden ikisi özyönetimi olumlayıcı niteliktedir ve özyönetim yetkinliklerinden biri olan kişinin duygularını anlaması ve kontrol edebilmesine işaret etmektedir. Bir deyim ise, özyönetim becerisindeki yetersizliği ifade etmesi nedeniyle anlamca olumsuzdur.

Bu bağlamda 'kendini yoklamak' deyimi; bireyin kendini duygu, düşünce ve beden bakımından kontrol etmesi anlamındadır. 'Nefsini köreltmek -körlemek-' deyimi de özyönetime yönelik olumlayıcı niteliktedir. Söz konusu deyim, beden isteklerinden her- 
hangi birini üstünkörü gidermek ve nefsini yatıştırmak olarak ifade bulmaktadır.

'Nefsine uymak' deyimi, kategori kapsamında özyönetime ilişkin olumsuzlayıcı niteliktedir. Deyim, bedenin isteklerine uymak ve günah işlemek olarak ifade bulmaktadır. Bu bağlamda özyönetim kaybını tanımlamaktadır.

\subsection{Bedensel Nitelikler İle Illgili Atasözleri ve Deyimler}

Beden, tek bir şekil ve görünüme sığabilmesi mümkün olmayan bir olgudur. Öyle ki türlü form ve boyutlarda ifade bulabilmektedir. Araştırma bulguları uyarınca, bedensel nitelikler ile ilgili Türkçede atasözü ve deyimlerin var olduğu bulgulamıştır. Söz konusu bulgular, Tablo. 6.'da sunulmuştur.

Tablo 6. Bedensel Nitelikler İle İlgili Türkçede Bulunan Atasözleri ve Deyimler

\begin{tabular}{|l|l|}
\hline \multicolumn{1}{|c|}{ Atasözü } & \multicolumn{1}{c|}{ Deyim } \\
\hline - Boyuma göre -boyumca- boy buldum, & - Dal gibi \\
huyuma göre -huyumca- huy bulmadım & - Filiz gibi \\
& - Heykel gibi \\
& - Kapı gibi \\
& - Manken gibi \\
& - Taşı sıksa suyunu çıkarır \\
& - Topaç gibi \\
\hline
\end{tabular}

Araştırma bulguları uyarınca Türkçede bedensel nitelikler ile ilgili, bir atasözü ile yedi deyimin mevcut olduğu görülmüştür. 'Boyuma göre -boyumca- boy buldum, huyuma göre -huyumca- huy bulmadım'; kategori kapsamındaki tek atasözüdür ve bir kimse, beden yapısı, zenginlik vb. konularda kendisine uyanı bulabilir ama huyu kendisine uyan bir kimseyi kolay kolay bulamaz anlamında kullanılmaktadır. Söz konusu atasözü kapsamında bir ilişkide bedensel uygunluğun, huy/mizaç uygunluğuna kıyasla görece daha az önemli ve az rastlanır olduğuna vurgu yapılmaktadır.

Kategori kapsamındaki deyimlere göz atıldığında, vücudun inceliği ve güzelliği ile ilgili deyimlerin sayısal fazlalığı dikkat çekmektedir. Bir diğer dikkat çeken bulgu, vücudun iriliği ve gürbüzlüğü ile ilgili deyimlerin varlığıdır.

Dal gibi', 'filiz gibi', 'heykel gibi' ve 'manken gibi' deyimleri; ince ve güzel vücut betimlemeleri ile dikkat çeken deyimlerdir. Bu bağlamda 'dal gibi' deyimi, ince uzun yapılı olarak ifade bulmaktadır. 'Filiz gibi' deyimi, ince ve güzel vücutlu demektir. 'Heykel gibi' deyimi, çok güzel vücut anlamına gelmektedir. 'Manken gibi' deyimi ise, vücut ölçüleri düzgün ve ince olarak karşılık bulmaktadır.

Vücudun iriliği ve gürbüzlüğü ile ilgili üç deyim bulunmaktadır. 'Kapı gibi' deyimi, iri vücutlu kimse demektir. 'Taşı sıksa suyunu çıkarır' deyimi, vücutça çok güçlü olmayı konu etmektedir. 'Topaç gibi' deyimi ise, vücutça toplu ve sağlıklı anlamına gelmektedir. Söz konusu deyimin bir diğer özelliği, çocuk bedeni ile ilgili olmasıdır. Kategori kapsamındaki diğer deyimler, yetişkinleri hedef almaktadır. 


\subsection{Beden Bakımı İle İlgili Atasözleri ve Deyimler}

TDK Büyük Türkçe Sözlük'e (2019) göre bakım; bir şeyin gelişmesi ve daha iyi bir durumda kalması için verilen emektir. Hayattaki her şey gibi, vücudun da bakıma ve özene intiyacı vardır. Vücut bakımı, vücudun sağlıklı ve zinde kalması için gerçekleştirilen eylem olarak tanımlanabilmektedir.

Gerçekleştirilen araştırma kapsamında, Türkçede beden bakımı ile ilgili deyimlerin varlığı tespit edilmiştir. Kategoriye ilişkin atasözü bulunmamaktadır. Söz konusu deyimler, Tablo. 7.'de sunulmuştur.

Tablo 7. Beden Bakımı İle İlgili Türkçede Bulunan Atasözleri ve Deyimler

\begin{tabular}{|l|l|}
\hline Atasözü & \multicolumn{1}{|c|}{ Deyim } \\
\hline & - İdman yapmak \\
& - Ot tutunmak \\
& - Ustura tutunmak \\
& - Vücut yapmak \\
& \\
\hline
\end{tabular}

Araştırma bulguları uyarınca Türkçede beden bakımı ile ilgili, dört deyimin bulunduğu görülmüştür. Söz konusu deyimlerden iki tanesi, bedeni kıllardan arındırmak; iki tanesi, bedeni daha güçlü yapmak ile ilgilidir. Kategori kapsamında, beden bakımının istenmeyen kıllardan kurtulma ve bedeni kuvvetlendirme ile ilişkilendirildiği saptanmıştır.

Bu bağlamda 'ot tutunmak' deyimi, vücuttaki istenmeyen kılları düşürmek için ilaç sürmek; 'ustura tutunmak' deyimi ise, vücuttaki istenmeyen kılları temizlemek olarak ifade bulmaktadır. Vücut kılları, insanın hayvansal var oluşunun bir simgesi olarak yorumlanmakta ve bu nedenle birçok kültürde arzulanır bulunmamaktadır. Morris, çok büyük beyinlere sahip kuyruksuz maymunlar olarak nitelediği insanların evrimsel süreçte bedensel olarak birçok değişikliğe uğradığına dikkat çekmektedir. Ona göre bilhassa kadın vücudu, evrimi sırasında erkek vücudundan çok daha ciddi değişikliklere maruz kalmıştır. Beden kılları; özellikle de kadınlar için Antik Mısır, Antik Yunan, Antik Roma, Türk, Arap ve Avrupa gibi kültürler başta olmak üzere birçok kültürde arzulanmamış ve yok edilmiştir (Morris, 2006: s. 269-283).

\subsection{Beden, İlișki ve İletișim Ile İlgili Atasözleri ve Deyimler}

Dilbilim, kültür çalışmaları ve iletişim araştırmalarına konu olan beden; dilin bedensel temelleri, beden metaforları, kültür-beden ilişkisi, beden imajı, beden dili gibi başlıklarda ele alınmaktadır. İnsansal var oluşun olmazsa olmaz unsuru olan iletişim, insana dair tüm alanları kapsamaktadır. Beden de, bu alanlardan biridir. Beden, insanın bir parçası ve diğer insanlara görünen yüzüdür. İnsanın bir uzantısı olması nedeniyle zihin, ruh ve davranış ile de bağlantııdır. Bu paralelde beden, kişilerarası iletişim ve ilişki kurma süreçlerinde de etkili bir rol oynamaktadır.

Araştırma bulguları uyarınca; beden, ilişki ve iletişim ile ilgili Türkçede atasözü ve deyimlerin var olduğu bulgulanmıştır. Söz konusu bulgular, Tablo. 8.'de sunulmuştur. 
Tablo 8. Beden, İlişki ve İletişim İle İlgili Türkçede Bulunan Atasözleri ve Deyimler

\begin{tabular}{|c|l|}
\hline \multicolumn{1}{|c|}{ Atasözü } & \multicolumn{1}{c|}{ Deyim } \\
\hline • Ağaca balta vurmuşlar, 'sapı bedenimden' demiş & $\begin{array}{l}\text { • Tek vücut olmak } \\
\text { • Yumruğuna güvenmek }\end{array}$ \\
& \\
\hline
\end{tabular}

Araştırma kapsamında Türkçede beden, ilişki ve iletişim ile ilgili, bir atasözü ve iki deyimin mevcut olduğu görülmüştür. 'Ağaca balta vurmuşlar, sapı bedenimden demiş', insana en yakını bile kötülük edebilir anlamında kullanılan bir atasözüdür.

Deyim kategorisine göz atılı̆̆ında ise; kolektif davranmaya gönderme yapan bir deyimin ve bireysel davranmaya gönderme yapan bir deyimin bulunduğu saptanmıştır. Bu bağlamda 'tek vücut olmak' deyimi, birlikte hareket etmek demektir. İnsanın diğer insanlarla birlikte hareket eden bir varlık olmasına gönderme yapan bu deyim, diğer insanlarla ortak davranmanın önemine dikkat çekmektedir. 'Yumruğuna güvenmek' deyimi ise, isteklerini yaptırmak için yalnızca bedensel gücüne güvenmek anlamına gelmektedir. Söz konusu deyim, tekil hareket etmeyi konu etmesinin yanı sıra insanın zihin gücüne değil, beden gücüne güvenmesini vurgulaması açısından dikkat çekicidir.

\subsection{Beden ve Giysi İle İlgili Atasözleri ve Deyimler}

Giyinmek; fiziki, doğal, toplumsal, ahlaki ve benzeri nedenlerle örtünüp korunmak için bir şeyi vücuduna geçirmek demektir. Giysi ise; en yalın ifadeyle giyilen, örtünülen, kuşanılan doğal ya da yapay nesnelerin tümüdür. Bedeni örtmesi ve her türlü dış etkenden koruması en önemli işlevidir. Bununla birlikte giysinin güzel ve çekici görünmeyi sağlaması, ait olunan toplumsal sınıfı belirtmesi, içinde bulunulan ruhsal durumu dışa vurması, geleneklerin ve modanın etkisini yansıtması gibi işlevleri de vardır.

Çağcıl dönemde giysiler, geçmiş dönemlere kıyasla daha farklı anlamlar ifade etmektedir. Öyle ki günümüzde giysiler; tüketimin en görünür biçimlerinden biri olarak, kimliğin kurulmasında da önemli bir rol oynamaktadırlar (Crane, 2003: s. 11). Bu bağlamda gerçekleştirilen araştırma kapsamında beden ve giysi ile ilgili Türkçede bir atasözü ve bir deyimin bulunduğu tespit edilmiştir. Söz konusu bulgular, Tablo. 9.'da sunulmuştur.

Tablo 9. Beden ve Giysi Ille Illgili Türkçede Bulunan Atasözleri ve Deyimler

\begin{tabular}{|c|c|}
\hline Atasözü & Deyim \\
\hline$\cdot$ Kalıp kıyafetle adam adam olmaz & $\cdot$ Ölçü almak \\
\hline
\end{tabular}

Araştırma bulguları uyarınca Türkçede beden ve giysi ile ilgili bir atasözü bulunmaktadır. Bu çerçevede 'kalıp kıyafetle adam adam olmaz' atasözü, gösterişli bir vücut ve iyi bir giyim kuşamın kişiye insanlık değeri katmayacağını ifade etmektedir. Günümüzün tüketime dayalı çok parçalı toplumlarında giysiler, medya süreçlerinin belirleyici hegemonyası altında sonsuz çeşitlilikte kimlik arayışı çabasının göstergeleri ve ifadeleri haline gelmiştir. Crane (2003), giysilerin artık ait olunan sınıfı değil, yaşam tarzımızı gösterir hale geldiklerini ifade ederek örtünmek için giydiğimiz giysileri, görünmek için giymeye başlayarak izleyen/izlenen olduğumuza ve birer görüntüye dönüştüğümüze 
dikkat çekmektedir. Böylesi bir toplum yapısı içinde, giysilerin insanı insan yapmaya yetmeyeceğini ifade eden bu atasözünün varlığı Türk kültürünün akıl -ruh- karşısında giyimle güzelleştirilen ve albenili hale getirilen bedeni nasıl konumlandırdığını ortaya koymak açısından da oldukça önemlidir.

Kategori kapsamında, bir deyim bulgulanmıştır. Söz konusu deyim, bedene ilişkin Türk Dil Kurumu Büyük Türkçe Sözlük'de (2019) verilen 'giysilerde ölçü' anlamına dayanmaktadır. Bu bağlamda 'ölçü almak' deyiminin herhangi bir şeyin boyutlarını ölçmek ve terzinin vücut ölçülerini tespit etmesi olmak üzere iki anlamı bulunmaktadır.

\section{Sonuc}

Beden, insanın cismani varlığıdır. Ancak yalnızca fiziksel bir olgu değildir, aynı zamanda toplumsal ve kültürel bir olgudur. Beden, toplumsal niteliği ile kültürü oluşturmakta ve değiştirmektedir. Toplumun değerlerinin, yaşayış biçiminin ve inançlarının bir yansıması olan beden; dilde de varlık bulmaktadır. Bu yönüyle beden, kültürün çeşitli boyutları hakkında mesajlar taşıyan atasözleri ve deyimlerin de konusudur. Beden ve beden ile ilişkili olguları içeren atasözü ve deyimlerin analizi yoluyla, bir kültürün beden olgusuna verdiği önem ve değeri, o kültürün bedene bakışını tespit etmek mümkündür.

Dilbilim ve kültür eksenli bu çalışmanın amacı, beden olgusunun Türk kültüründeki yerini ve önemini Türkçe üzerinden araştırmayı amaçlamaktır. Bu yönelimle Türk Dil Kurumu Atasözleri ve Deyimler Sözlüğü araştırma evreni olarak seçilmiştir. Araştırma kapsamında, kriter örnekleme ile belirlenen atasözleri ve deyimler, anlam temelinde kategorilere ayrılmış ve içerik analizine tabi tutulmuştur. Kategoriler araştırmacılar tarafından bizzat oluşturulmuş olup araştırmanın kısıtı, araştırma evrenine dahil edilmeyen atasözleri ve deyimler sözlükleridir.

Araştırma bulgularının genel yorumunda, Türkçede beden olgusu ile ilgili atasözleri ve deyimlerin bulunduğu görülmüştür. Bu durum, Türk kültüründe beden olgusunun önemsendiği şeklinde değerlendirilmiştir. Bulguların atasözü ve deyim dağılımı incelendiğinde, deyimlerin atasözlerine kıyasla daha fazla olduğu tespit edilmiştir. Daha açık bir ifadeyle araştırma kapsamında beden olgusunun deyim yapıları içinde yoğun olarak kullanıldığı ve anlam aktarımı sağladığı saptanmıştır. Bu tespit, daha önce gerçekleştirilen çalışmalarla benzer sonuçları içermektedir. Çelik (2017), Özezen ve Ördem (2014) gerçekleştirdikleri araştırmalarda Türkçedeki deyimleri incelemiş, Türkçenin zengin deyim varlığına sahip bir dil olduğunu ve organ isimleri ile beden bölümlerinin deyim yapıları içinde sıklıkla kullanılarak anlam üretiminde etkili rol oynadığını bulgulamışlardır.

Araştırma kapsamında beden ve sağlık ile ilgili atasözü ve deyimlerin, diğer kategorilere kıyasla görece fazla olduğu görülmüştür. Sağlık, beden ile doğrudan ilgili bir olgudur ve olası bir sağlık sorunu doğrudan beden üzerinden kendini göstermektedir. Söz konusu bulgu uyarınca Türk toplumunun beden sağlığını önemsediği ve tüm servetlerin üzerinde tuttuğunu ifade etmek mümkündür. 'Baş sağlığı, dünya varlığı', 'başın sağlığı, dünyanın varlığı', 'her işin -şeyin- başı sağlık' atasözleri; Türk kültüründe sağlığın ve zindeliğin maddi olan her şeyin üzerinde bir anlam ifade ettiğine ve en temel zenginlik kaynağı olduğuna göndermede bulunmaktadır. 
Beden ve sağlık hakkındaki atasözü ile deyimlerle ilintili diğer bir bulgu, hastalık durumunu ifade eden deyimlerin, sağlık durumunu ifade eden deyimlere kıyasla sayısal çokluğudur. Arık, 1991 yılında gerçekleştirdiği çalışmasında Türklerin Anadolu ile dünya üzerinde yerleştikleri diğer coğrafyalarda tarihin farklı dönemlerinde salgın hastalıklarla mücadele ettiklerini dile getirmiştir. Halkı ve toplumsal yaşamdaki pratikleri önemli ölçüde etkilemiş hastalıkların temel göstergelerinin -ateş ve hararet gibi-, Türkçenin söz varlığına yansımış olmasının, hastalığa işaret eden deyimlerin sayısal çokluğu ile açıklanabileceğini ifade etmek olanaklıdır. Öyle ki Tavkul da 2016 yılında gerçekleştirdiği araştırmasında, günümüzde bazı Türk lehçelerinin söz varlığında, salgın hastalıktan kurtulan birinin büyük bir yangın felaketinden de kurtulma becerisini kazanacağı öngörüsünü aktaran atasözlerinin mevcut olduğunu tespit etmiştir.

Araştırma kapsamında dikkat çeken bir diğer bulgu, bedenin nitelikleri ile ilgili atasözü ve deyimlerin varlığıdır. Kategori kapsamındaki tek atasözü olan 'boyuma göre -boyumca- boy buldum, huyuma göre -huyumca- huy bulmadım'; ilişkilerde beden yapısına uygunluğu bulmanın kolay olduğunu, ancak huy uygunluğunu bulmanın kolay olmadığını savlamaktadır.

Bedenin nitelikleri ile ilgili deyimlerin temasal dağılımı ise, Türk kültüründe beden inceliğinin ve güzelliğinin önemsendiğini düşündürmektedir. 'Dal gibi', 'filiz gibi', 'heykel gibi', 'manken gibi' betimlemelerini konu alan deyimler; bu saptamayı doğrulamaktadır. Çiçek, 2018 yılında gerçekleştirdiği çalışmasında, tarihsel kaynaklarda özellikle Ortaçağ yabancı kaynaklarında, Türklerin bedenlerinin sağlam ve güzel olduğu bahsinin geçtiğini ifade etmektedir. Bu paralelde Türk kültürünün beden güzelliğine ve inceliğine verdiği önemin, deyimler üzerinden de okunabildiği yorumunu yapmak mümkündür.

Bedensel nitelikler kapsamında irilik ve gürbüzlük de, tıpkı incelik ve güzellik gibi Türk kültüründe önemsenen değerlerdir. 'Kapı gibi' ve 'topaç gibi' betimlemelerini içeren deyimler, söz konusu bulguya ilişkin kanıtlardır. Araştırma kapsamında çocuk bedeni ile ilgili ulaşılan tek deyim olan 'topaç gibi', Türk kültürünün çocuk söz konusu olduğunda vücutça toplu ve sağlıklı olmayı önemsediğini düşündürmektedir. Bu paralelde 'taşı sıksa suyunu çıkarır' deyimi de, Türk toplumunun vücutça iriliğin zor durumların altından kolayca kalkmayı ve başarılı olmayı sağlayacağı inancına sahip olduğu şeklinde yorumlanabilmektedir.

Araştırma kapsamında elde edilen bir diğer bulgu, beden ve spor ile ilgili deyimlerin varlığıdır. Spor, insana özgü bir etkinliktir ve bedensel hareketleri içermektedir. Bu kapsamda bulgulanan vücut gelişimi ile ilgili deyimler, Türk kültüründe beden ve spor olgularının önemsendiğini düşündürmektedir.

Vücut iriliğinin ve gürbüzlüğünün yanı sıra beden ve spor ile ilgili elde edilen bulgular ışı̆̆ında, bu araştırmada, daha önce gerçekleştirilen çalışmalara benzer sonuçlara ulaşıldığını ifade etmek mümkündür. Dever ve İslam, 2015 yılında gerçekleştirdikleri çalışmalarında; Türklerin tarihsel süreçte bedene, bedensel kuvvete ve beden hareketlerine önem atfettiklerini ifade etmiştir. Onlara göre, Eski Türk medeniyetlerinde bedenin güçlü ve sağlıklı olması demek, askeri anlamda da güçlü olmak demektir. Diğer bir deyişle Türklerin güçlü ve sağlıklı olabilmek için, beden idmanlarını bir 
yaşam biçimi haline getirdiğini ileri sürmek mümkündür. Bir dilin söz varlığının o dili konuşan bireylerin günlük yaşam uygulamalarını ve bu uygulamalarla ilişkili olgu ve durumları yansıttığı gerçeğinden hareketle, Türklerin günlük yaşamlarında beden ve bedenle ilişkili pratiklerin geniş yer kaplamasının, Türkçenin söz varlığını etkilediği yorumu yapılabilmektedir.

Araştırma kapsamındaki bir diğer bulgu, beden bakımı ile ilgili deyimlerin mevcudiyetidir. Beden bakımı; bedenin sağlıklı, zinde ve temiz kalması için gerçekleştirilen tüm eylemleri içermektedir. Bulgular uyarınca Türk kültüründe bedenin önemsenmesine koşut olarak beden bakımının da önemsendiği sonucunu çıkarmak mümkündür.

Araştırmaya ilişkin diğer bulgu, beden ve özyönetim ile ilgilidir. Özyönetim; kişinin içsel potansiyeli, yeterlilikleri ve yetkinlikleri ile ilgili bir kavramdır. Bedenin kişinin bir parçası olması nedeniyle, özyönetim beden ile bağlantılı bir kavram ve uygulama alanıdır. Türk kültüründe beden ve özyönetim ilişkisini, araştırma kapsamında saptanan deyimler aracılığıyla çözümlemek mümkündür.

Araştırma kapsamında beden ve iletişim bağlantısına işaret eden atasözü ve deyimlere ulaşılması, bir diğer bulgudur. İletişim, dilin en temel işlevidir. İnsanlar bedenleri aracılığıyla iletişime girmekte ve toplumsal ilişkilerini yürütmektedir. Araştırma bulguları ışığında Türk kültüründe beden, ilişki ve iletişim temalarının birlikte ele alındığına dikkat çekilebilmektedir. Bu bağlamda Türk toplumunda bireysel davranmanın da, diğer insanlarla birlikte hareket etmenin de eşit kabul gördüğü yorumunu yapmak olanaklıdır.

Araştırmaya ilişkin bir diğer bulgu, beden ve giyim ile ilgili atasözü ve deyimlerin sayıca az olmasıdır. Kategori kapsamında yer alan bir atasözü, Türk kültüründe 'beden-akıl' karşılığını vurgulaması açısından dikkat çekicidir. Söz konusu atasözünden hareketle, Türk toplumunda giysilerin insanı insan yaptığına ve kişiliğe değer kattığına inanılmadığını düşünmek olanaklıdır. Bu bağlamda Türk kültüründe bir kişinin toplumda kabul görmesi için başka özelliklere de -akıl, erdem vb.- sahip olması gerektiğine inanılmaktadır.

Sonsöz olarak bu çalışma, beden olgusunu Türkçede bulunan atasözleri ve deyimler üzerinden analiz ederek beden araştırmaları alanyazınında önemli bir boşluğu doldurmayı hedefleyen sınırlı sayıdaki çalışmalardan birisidir. Ancak elbette ki alanda yeni çalışmalara intiyaç vardır. Bu çalışmanın, daha sonra yapılacak olan çalışmalara bir yol haritası oluşturması beklenmektedir. Tüm bu bulgular ve varılan sonuçlar doğrultusunda, ileriki araştırmalara yönelik şu öneriler sunulabilmektedir.

- Araştırmanın verileri, TDK Atasözleri ve Deyimler Sözlüğü’nden elde edilmiştir. Diğer atasözleri ve deyimler sözlüklerinin araştırma evreni olarak seçildiği farklı araştırmalar gerçekleştirilebilir.

- Araştırma, 'beden' ve 'vücut' kelimelerinin Türkçede bulunan atasözleri ve deyimler nezdinde taranması ile gerçekleştirilmiştir. Beden bölümlerini ve organları temel alan atasözü ve deyim araştırmaları gerçekleştirilebilir.

- Araştırma, Türkçeye ve Türk kültürüne odaklanmıştır. Beden olgusunun farkı dil ve kültürlerdeki yer ve önemini konu eden araştırmalar gerçekleştirilerek kültürler arası karşılaştırmalar yapılabilir. 


\section{Kaynakça}

Akarsu, B. (1975). Felsefe Terimleri Sözlüğü. Ankara: Türk Dil Kurumu Yayınları.

Arık, Ş. F. (1991). Selçuklular Zamanında Anadolu'da Veba Salgınları. Tarih Araştırmaları Dergisi, s. 27-57.

Başak, R. (2016). Musevilikte Sanat ve Estetik Anlayışı. İdil-Sanat ve Dil Dergisi, 5 (21): s. 477490.

Baudrillard, J. (1998). The Consumer Society: Myths and Structures. England: Sage Publications.

Bayram, M., Aka, T. S., Geçit, S. M. ve Şebin, K. (2019). İslamda Sporun Önemi ve Ahlakı. Ağrı İbrahim Çeçen Üniversitesi Sosyal Bilimler Enstitüsü Dergisi, 5 (1): s. 207-224.

Cimini, A. (2012). Vibrating Colors and Silent Bodies. Music, Sound and Silence in MauriceMerleau-Ponty's Critique of Dualism. Contemporary Music Review, 31 (5-6): s. 353-370.

Crane, D. (2003). Moda ve Gündemleri. Ö. Çelik (Çev.), İstanbul: Ayrıntı Yayınları.

Çelik, Y. (2017). Türkiye Türkçesinde Duyu Organlarıyla Kurulan Deyimler. Uluslararası Sosyal Araştırmalar Dergisi, Cilt: 10, Sayı 50: s. 72-79.

Çiçek, A. (2018). Orta Asya Türk Toplumlarının Sosyo-Kültürel Yapısının Genel Bir Değerlendirilmesi. Mavi Atlas, 6 (1): s. 233-247.

Çil, H. (2017). Toplumsal Dünyanın Bedensel Temelleri: Durkheim, Weber ve Simmel Sosyolojisinde Bedenin Yeri. SEFAD-Selçuk Üniversitesi Edebiyat Fakültesi Dergisi, Sayı: 37: s. 449-464.

Demello, M. (2014). Body Studies: An Introduction. UK: Routledge.

Demir, T. (2018). Kutsaldan Sekülere Değişen Beden Algısı. Şırnak Üniversitesi Illahiyat Fakültesi Dergisi, 9 (2): s. 311-325.

Demir, Z. (2018). Karl Marx'ın Bakış Açısından Kapitalist Toplumda Yabancılaşma ve Sonuçları. Abant Kültürel Araştırmalar Dergisi, 3 (5): s. 63-74.

Dever, A. ve İslam, A. (2015). Tarihsel Süreç İçerisinde Türk Kültüründe Spor Algısı. Manas Sosyal Araştırmalar Dergisi, 4 (5): s. 46-61.

Dikkol, S. (2016). Conatus'tan Habitus'a Birey/Toplum ve Akıl/Beden İkiliğini Aşmaya Yönelik Bir Deneme. Toplum ve Demokrasi Dergisi, 10 (21): s. 1-11.

Duman, F. (2010). Toplumsal Hafıza, (Fransız) Devrim(i) ve Sosyal/Siyasal Kuram. Gelenekten Geleceğe Muhafazakar Düşünce, Yıl 6, Sayı 24: s. 13-40.

Durkheim, E. (2005). The Dualism of Human Nature and Its Social Conditions. Durkheimian Studies / Études Durkheimiennes, Vol. 11: s. 35-45.

Eichberg, H. (2009). Body Culture. Physical Culture and Sport Studies and Research, Sayı: 46: s. $79-98$.

Foucault, M. (2000). The Birth of Social Medicine. J. D. Faubion (ed.). Power: Essential Works 
of Foucault 1954-1984. London: Penguin, s. 134-156.

Freedman, J. L., Sears, D. O. ve Carlsmith, J. M. (2003). Sosyal Psikoloji. 4. Baskı. A. Dönmez (Çev.), Ankara: İmge Kitabevi.

Giddens, A. (2000). Sosyoloji. H. Özel, P. W. Sutton (Çev.), Ankara: Ayraç Yayınevi.

Hançerlioğlu, O. (1994). Felsefe Sözlüğü. İstanbul: Remzi Kitabevi.

Harper, D. (2019). Body. Online Etymology Dictionary. 31 Temmuz 2019 tarihinde https://www. etymonline.com/search?q=body adresinden edinilmiştir.

Henry, M. (1975). Philosophy and Phenomenology of the Body. Netherlands: Martinus Nijhoff.

Hira, I. (2000). Yasa Koyucu Tasarımdan Yorumcu Tasarıma. Bilgi Sosyal Bilimler Dergisi, Sayı: 3: s. 81-97.

İmamoğlu, V. A. (1995). Ruh Beden Ilişkisi. Atatürk Üniversitesi Ilahiyat Fakültesi Dergisi, Sayı: 1: s. 345-356.

Jacobs, R. L. (2001). Using Human Resources Functions to Enhance Emotional Intelligence. C. Cherniss, D. Goleman (ed.). The Emotionally Intelligent Workplace. USA: Jossey Bass, s.159181.

Kalelioğlu, U. B. (2018). Pozitivizmin Epistemolojik Temeli ve Avrupamerkezci Sosyolojik Bilginin Sınırları. Uluslararası Multidisipliner Akademik Çalışmalar Sempozyumu, İstanbul: s. 851-865.

Kaya, M. (2013). Platon'un Ruh Kuramı. Sosyal Bilimler Dergisi, Sayı: 1: s. 171-182.

Ketenci, T. (2014). Descartes ve Hume'un Akıl Anlayışlarının Karşılaştııılması. Temaşa-Erciyes Üniversitesi Felsefe Bölümü Dergisi, 1 (1): s. 61-77.

Krippendorf, K. (2004). Content Analysis: An Introduction to its Methodology. USA: Sage Publications.

Lange, A. F. (2001). The Histoy of Materialism. USA: Routledge.

Marshall, G. (1999). Sosyoloji Sözlüğü. O. Akınhay ve D. Kömürcü (Çev.), Ankara: Bilim ve Sanat Yayınları.

Melin, R. (2013). Instrumentalization of the Body in Sports. 20 Haziran 2019 tarihinde http:// www.idrottsforum.org/melin131118 adresinden edinilmiştir.

Morris, D. (2006). Çıplak Kadın-Kadın Vücudu Üzerine Bir İnceleme. A. Özer (Çev.), İstanbul: İnkilap Kitabevi.

Mutlu, E. (2004). İletişim Sözlüğü. 4. Baskı. Ankara: Bilim ve Sanat Yayınları.

Nazlı, A. (2009). Sosyolojik Bakışın Eşiğindeki Beden. Toplumbilim Dergisi, Sayı: 24: s. 61-68.

Oskay, Ü. (2004). Peki Konuşalım! Popüler Kültür Üzerine. İstanbul: Epsilon Yayınları.

Outram, D. (1989). The Body and the French Revolution. USA: Yale University Press.

Özezen, Y. M. ve Ördem, E. (2014). Yüz Kuramları Çerçevesinde Dil-Beden İlişkisi ve Türkiye Türkçesi -Bilişsel Dilbilimsel Bir Yaklaşım, International Journal of Language Academy, 2 (1): s. 
$151-177$

Palabıyık, A. (2011). Pierre Bourdieu Sosyolojisinde 'Habitus', 'Sermaye' ve 'Alan' Üzerine. Liberal Düşünce, Sayı 61-62: s. 121-141.

Potte-Bonneville, M. (2012). Michel Foucault's Bodies. The Journal of the British Society for Phenomenology, 43 (1): s. 1-32.

Richardson, N. ve Locks, A. (2014). Body Studies: The Basics. USA: Routledge.

Shilling, C. (1993). The Body and Social Theory. London: Sage Publications.

Shilling, C. (2005). The Body in Culture Technology and Society. Great Britain: Sage Publications.

Tavkul, U. (2016). Karaçay-Malkar Türkçesinde Hastalık Adları ve Bununla İlgili Bazı Fiiller, Deyimler ve Atasözleri, Modern Türklük Araştırmaları Dergisi, 13 (3): s. 111-122.

Turner, S. B. (2012). The Turn of the Body. B. S. Turner (ed.). Routledge Handbook of Body Studies. USA: Routledge.

Türk Dil Kurumu (2019). Atasözleri ve Deyimler Sözlüğü. 15 Mart 2019 tarihinde http://www.tdk. gov.tr adresinden edinilmiştir.

Türk Dil Kurumu (2019). Büyük Türkçe Sözlük. 15 Mart 2019 tarihinde http://www.tdk.gov.tr adresinden edinilmiştir.

Weber M. (2012). The Protestant Ethic and the Spirit of Capitalism. USA: Courier Corporation.

-, Cambridge Dictionary (2019). Body. 30 Mayıs 2019 tarihinde https://dictionary.cambridge.org/ tr/s\%C3\%B6zl\%C3\%BCk/ingilizce/body adresinden edinilmiştir.

-, Lexico's Dictionary \& Thesaurus (2019). Body. 30 Mayıs 2019 tarihinde https://dictionary. cambridge.org/tr/s\%C3\%B6zl\%C3\%BCk/ingilizce/body adresinden edinilmiştir. 